\title{
Nutrient uptake and growth of spinach as affected by cow manure co-composted with poplar leaf litter
}

\author{
Zobia Anwar $^{1} \cdot$ Muhammad Irshad $^{1} \cdot$ Qaisar Mahmood $^{1} \cdot$ Farhan Hafeez $^{1} \cdot$ \\ Muhammad Bilal ${ }^{1}$
}

Received: 20 September 2016/ Accepted: 13 January 2017/Published online: 25 January 2017

(c) The Author(s) 2017. This article is published with open access at Springerlink.com

\begin{abstract}
Purpose Wastes were composted and applied as the soils amendment to improve soil fertility and crop productivity. The study aimed at assessing the nutrient uptake and growth of spinach (Spinacia oleracea L.) grown in soils amended with cow manure after a co-composting process. Methods Sandy loam and silt loam soils were amended with cow manure after co-composting with poplar leaf litter at 1:0, 1:1, 1:2 and 1:3. The compost was applied to soil at the rate of $20 \mathrm{tha}^{-1}$. Spinach was grown for 8 weeks and then harvested to measure plant shoot biomass. Spinach shoot samples were digested and nutrient contents in the shoots were determined.

Results Co-composted manure significantly improved the growth and nutrients availability to the spinach. Dry biomass, $\mathrm{P}$ and $\mathrm{K}$ contents in spinach shoot varied among manure: leaf litter ratios: 1:0<1:1<1:2<1:3. Conversely, $\mathrm{N}, \mathrm{Zn}, \mathrm{Fe}, \mathrm{Cu}$ and $\mathrm{Cd}$ contents in spinach shoot reduced with the manure amendment with increasing amount of leaf litter. Water extractable micro-elements in the post-harvest soils were found in the order of $\mathrm{Zn}>\mathrm{Fe}>\mathrm{Cu}>\mathrm{Cd}$. Co-compost amendments increased the $\mathrm{P}$ and $\mathrm{K}$ availability except $\mathrm{N}, \mathrm{NO}_{3}$ and $\mathrm{NH}_{4}$ in the post-harvest soils. Trace elements in the post-harvest soils reduced with leaf additives in the compost.

Conclusions Co-composted cow manure with leaf litter proved to be superior in terms of bioavailability of plant nutrients over the composted manure without leaf litter.
\end{abstract}

Muhammad Irshad

mirshad@ciit.net.pk

1 Department of Environmental Sciences, COMSATS Institute of Information Technology, Abbottabad, Pakistan
This may also assist in mitigating the environmental contamination of heavy metals in the farm lands.

Keywords Spinach growth · Nutrient content · Cow manure $\cdot$ Leaf litter $\cdot$ Co-composting

\section{Introduction}

In developing countries, continuous application of inorganic fertilizer in conjunction with paucity of technical prowess among farmers comprises nutrient imbalance in soil and environmental pollution (Azza et al. 2007). Escalating costs of inorganic fertilizers have directed the attention of farmers towards organic sources which enhance soil fertility possibly by improving physicochemical properties of soils. These may involve nutrient availability and uptake, soil texture, water holding capacity, cation exchange capacity, electrical conductivity, $\mathrm{pH}$, microbial population and soil organic matter (Agbede et al. 2008; Muhammad and Khattak 2009). Likewise, increasing urbanization is intensifying inappropriate management and disposal of organic wastes from different sources, thereby deteriorating the environmental quality and subsequent food chain contamination through bio-magnification (Mrabet et al. 2012; Benjawan et al. 2015). Organic residues constitute valuable plant nutrients which can be transformed into high yielding soil amendments via composting (Silva et al. 2007). Simultaneously, this potentially resourceful soil amendment is being wasted, demonstrating a reduction in the progressive productivity. Intensive cultivation has triggered decline in the soil organic matter (Giannakis et al. 2014).

The application of compost is a common practice for heavy metals immobilization and soil amelioration. It was 
reported that organic amendments could reduce the bioavailability of heavy metals in contaminated soils (Gul et al. 2016). Composting was suggested as the sustainable soil fertility management option for teeming population, as well as the strategy for recycling a variety of organic residues, resulting in the reclamation of degraded soils $(\mathrm{Li}$ et al. 2008). The reuse of organic wastes in agriculture is an appropriate method of environment management (Torkashvand et al. 2015). Livestock industry produces a great amount of solid waste in Pakistan which pollutes the environment. Moreover, large amount of plant residues especially from different trees including leaf litter is also generated daily which is a potential environmental hazard via land-filling and incineration of these carbon pools (Chaudhry et al. 1999). Therefore, their effective utilization through co-composting of organic wastes to amend nutrient deficient soil and to increase bio-available fraction for plant uptake is yet to be explored. Therefore, an attempt was made to study the nutrient uptake efficiency, growth and extractable plant nutrients in soils as influenced by cow manure co-composted with poplar leaf litter.

\section{Materials and methods}

\section{Composting process}

The raw materials for composting were cow manure and leaf litter of poplar (Populus tremula L.). These materials were collected from Abbottabad area $\left(34.1558^{\circ} \mathrm{N}\right.$, $73.2194^{\circ} \mathrm{E}$ ), Pakistan. Cow manure was co-composted with poplar leaf litter in plastic composting bins $(15 \mathrm{~L})$ at the cow manure to leaf litter ratios of 1:0, 1:1, 1:2 and 1:3 (mass basis) for 120 days. Each treatment was in triplicate. During the composting process, manure samples were occasionally aerated and moistened to about $30 \%$ at room temperature on weekly basis. Samples were collected after 120 days of composting, air dried and passed through a $2 \mathrm{~mm}$ sieve for the determination of relevant parameters (Table 1).

\section{Greenhouse study}

Two types of soils (sandy loam and silt loam) were sampled at a depth of 0-20 cm from nearby agricultural fields of Abbottabad city. The samples were air-dried for two days and screened through a $2 \mathrm{~mm}$ sieve. The physicochemical properties of soils were determined using the methodologies given in Table 2. A pot experiment was carried out in plastic pots. Each pot was filled with $10 \mathrm{~kg}$ soil. Co-composted manures were thoroughly mixed with these soils at the application rate of $20 \mathrm{t} \mathrm{ha}^{-1}$ (based on 2 million $\mathrm{kg}$ soil per plow layer per ha). Co-composted amendments were applied to two types of soils and were compared with the soil applied with manure composted without plant litter (1:0). This treatment was considered as a control. The experiment was a $(4 \times 2)$ factorial (ratio of cow manure co-composted with plant residues $\times$ soil types) resulting in eight experimental units which were arranged in a completely randomized block design. Each experimental unit was installed in triplicate. Irrigation was applied twice the daily pan evaporation. Spinach (Spinacia oleracea L.) was grown for 8 weeks as test crop and then harvested for plant shoot biomass. Subsequently, plants were thoroughly rinsed with distilled water and oven dried for $48 \mathrm{~h}$ at $60{ }^{\circ} \mathrm{C}$. Plants' shoots were oven dried for $48 \mathrm{~h}$ at $60{ }^{\circ} \mathrm{C}$. The dry weight of spinach was calculated. The samples were milled and digested as given below.

\section{Analytical methods}

Dry combustion method was used to determine total carbon in the composted manure (Nelson and Sommers 1982). Total organic matter was determined by multiplying the total carbon values by 1.72 (Nelson and Sommers 1982). Total content of nitrogen $(\mathrm{N})$ was determined by Kjeldahl method. Soil, milled composted manure and spinach shoot samples were digested in a mixture (1:3) of perchloric $\left(\mathrm{HClO}_{4}\right)$ and nitric $\left(\mathrm{HNO}_{3}\right)$ acids to determine the total elemental composition of phosphorous $(\mathrm{P})$, potassium $(\mathrm{K})$, copper $(\mathrm{Cu})$, iron $(\mathrm{Fe})$, zinc $(\mathrm{Zn})$ and cadmium $(\mathrm{Cd})$ in the extracts (Miller 1998). Spectrophotometer (Stalwart UV 900 USA) determined the $\mathrm{P}$ contents in all samples (soil, manure and plant) through phosphomolybdate blue method. Absorbance was determined at a wavelength of $710 \mathrm{~nm}$ (Olsen and Sommers 1982). Cationic elements in the soil, manure and plant samples were determined using atomic absorption spectrometer (AAS) (Model AAnalyst 700, Perkin-Elmer, Waltham, MA, USA). The $\mathrm{pH}$ and electrical conductivity (EC) of soil and organic manures samples were measured in watermanure and water-soil suspensions of 1:5 ratio with $\mathrm{pH}$ (Janway 3505) and EC (Janway 470) meters. Nitrate-N and $\mathrm{NH}_{4}-\mathrm{N}$ were extracted from soil and manure by shaking $2 \mathrm{~g}$ of sample in $2 \mathrm{M} \mathrm{KCl}$ solutions for $1 \mathrm{~h}$ in $25 \mathrm{~mL}$ polypropylene centrifuge tubes on an end-over-end shaker, then centrifuged at 10,000 rpm for $10 \mathrm{~min}$ and supernatant was analyzed. Ammonium- $\mathrm{N}$ was determined following the indophenol blue method (Keeney and Nelson 1982), whereas the $\mathrm{NO}_{3}-\mathrm{N}$ was determined according to Anderson and Ingram (1993) and read from the spectrophotometer at 635 and $410 \mathrm{~nm}$, respectively. Particle size distribution of the soil was measured by the pipette method (Gee and Bauder 1986). The soils used during the study were classified as sandy loam on the basis of $57 \%$ sand, $24 \%$ silt and $19 \%$ clay and loamy sand on the basis of $70 \%$ sand, $17 \%$ silt and $13 \%$ clay. 
Table 1 Chemical composition of manure co-composted with poplar leaf litter at different ratios

\begin{tabular}{llcccc}
\hline Parameters & Unit & $1: 0$ & $1: 1$ & $1: 2$ & $1: 3$ \\
\hline Total C & $\mathrm{g} \mathrm{kg}^{-1}$ & $366.8 \pm 14$ & $374.4 \pm 16$ & $378.3 \pm 16$ & $397.5 \pm 15$ \\
Total N & $\mathrm{g} \mathrm{kg}^{-1}$ & $18.0 \pm 2$ & $16.7 \pm 2$ & $15.6 \pm 2$ & $15.0 \pm 2$ \\
$\mathrm{NO}_{3}-\mathrm{N}$ & $\mathrm{mg} \mathrm{kg}^{-1}$ & $91.6 \pm 10$ & $86.8 \pm 11$ & $74.5 \pm 8$ & $67.9 \pm 7$ \\
$\mathrm{NH}_{4}-\mathrm{N}$ & $\mathrm{mg} \mathrm{kg}^{-1}$ & $59.6 \pm 6$ & $60.3 \pm 7$ & $57.6 \pm 6$ & $34.8 \pm 3$ \\
Total P & $\mathrm{mg} \mathrm{kg}^{-1}$ & $169.7 \pm 8$ & $180.9 \pm 9$ & $196.4 \pm 8$ & $206.3 \pm 10$ \\
Total Ca & $\mathrm{mg} \mathrm{kg}^{-1}$ & $167.2 \pm 11$ & $178.6 \pm 10$ & $188.2 \pm 9$ & $203.6 \pm 12$ \\
Total Mg & $\mathrm{mg} \mathrm{kg}^{-1}$ & $132.6 \pm 9$ & $143.9 \pm 9$ & $165.2 \pm 6$ & $172.6 \pm 10$ \\
Total K & $\mathrm{mg} \mathrm{kg}^{-1}$ & $400.4 \pm 15$ & $467.9 \pm 17$ & $489.0 \pm 17$ & $511.8 \pm 21$ \\
Total Na & $\mathrm{mg} \mathrm{kg}^{-1}$ & $41.0 \pm 3$ & $33.4 \pm 2$ & $31.2 \pm 2$ & $25.6 \pm 1.8$ \\
Total Cu & $\mathrm{mg} \mathrm{kg}^{-1}$ & $93.1 \pm 6$ & $63.5 \pm 3$ & $66.2 \pm 4$ & $56.1 \pm 2$ \\
Total Fe & $\mathrm{mg} \mathrm{kg}^{-1}$ & $184.9 \pm 13$ & $166.4 \pm 10$ & $167.1 \pm 7$ & $154.4 \pm 9$ \\
Total Mn & $\mathrm{mg} \mathrm{kg}^{-1}$ & $124.8 \pm 8$ & $105.2 \pm 5$ & $98.5 \pm 7$ & $82.7 \pm 6$ \\
Total $\mathrm{Zn}$ & $\mathrm{mg} \mathrm{kg}^{-1}$ & $140.6 \pm 14$ & $115.2 \pm 10$ & $100.2 \pm 10$ & $87.5 \pm 7$ \\
Total Ni & $\mathrm{mg} \mathrm{kg}^{-1}$ & $2.7 \pm 0.2$ & $2.3 \pm 0.2$ & $1.8 \pm 0.2$ & $1.9 \pm 0.2$ \\
Total Cd & $\mathrm{mg} \mathrm{kg}^{-1}$ & $1.5 \pm 0.1$ & $1.1 \pm 0.1$ & $1.0 \pm 0.1$ & $0.9 \pm 0.1$ \\
EC (1:5) & $\mathrm{dS} \mathrm{m}^{-1}$ & $5.0 \pm 0.8$ & $6.1 \pm 0.8$ & $6.3 \pm 1$ & $6.8 \pm 0.9$ \\
pH (1: 5$)$ & & $8.7 \pm 1$ & $8.3 \pm 1$ & $8.1 \pm 1$ & $7.7 \pm 0.6$ \\
\hline
\end{tabular}

\pm values indicate standard deviation
Table 2 Chemical composition of soils used for the experiment

\begin{tabular}{llcc}
\hline Parameters & Unit & Sandy loam soil & Silt loam soil \\
\hline Total C & $\mathrm{g} \mathrm{kg}^{-1}$ & $25.6 \pm 2$ & $28.3 \pm 2$ \\
Total N & $\mathrm{mg} \mathrm{kg}^{-1}$ & $35.8 \pm 3$ & $56.6 \pm 4$ \\
$\mathrm{NO}_{3}-\mathrm{N}$ & $\mathrm{mg} \mathrm{kg}^{-1}$ & $6.6 \pm 1$ & $15.3 \pm 2$ \\
$\mathrm{NH}_{4}-\mathrm{N}$ & $\mathrm{mg} \mathrm{kg}^{-1}$ & $8.2 \pm 1$ & $10.8 \pm 1$ \\
Total $\mathrm{P}$ & $\mathrm{mg} \mathrm{kg}^{-1}$ & $45.7 \pm 2$ & $67.8 \pm 3$ \\
Total Ca & $\mathrm{mg} \mathrm{kg}^{-1}$ & $218.7 \pm 8$ & $267.8 \pm 12$ \\
Total $\mathrm{Mg}$ & $\mathrm{mg} \mathrm{kg}^{-1}$ & $128.6 \pm 6$ & $131.6 \pm 6$ \\
Total K & $\mathrm{mg} \mathrm{kg}^{-1}$ & $147.8 \pm 7$ & $158.8 \pm 8$ \\
Total Na & $\mathrm{mg} \mathrm{kg}^{-1}$ & $23.4 \pm 3$ & $34.6 \pm 4$ \\
Total Cu & $\mathrm{mg} \mathrm{kg}^{-1}$ & $34.5 \pm 4$ & $56.4 \pm 3$ \\
Total $\mathrm{Fe}$ & $\mathrm{mg} \mathrm{kg}^{-1}$ & $67.8 \pm 5$ & $78.6 \pm 6$ \\
Total $\mathrm{Mn}$ & $\mathrm{mg} \mathrm{kg}^{-1}$ & $47.5 \pm 4$ & $67.5 \pm 6$ \\
Total $\mathrm{Zn}$ & $\mathrm{mg} \mathrm{kg}^{-1}$ & $56.7 \pm 4$ & $76.9 \pm 5$ \\
Total $\mathrm{Ni}$ & $\mathrm{mg} \mathrm{kg}^{-1}$ & $2.5 \pm 0.2$ & $3.0 \pm 0.2$ \\
Total Cd & $\mathrm{mg} \mathrm{kg}^{-1}$ & $0.3 \pm 0.1$ & $1.9 \pm 0.1$ \\
EC (1:5) & $\mathrm{dS} \mathrm{m}^{-1}$ & $0.5 \pm 0.1$ & $0.3 \pm 0.02$ \\
pH (1: 5$)$ & & $7.6 \pm 0.7$ & $7.8 \pm 0.7$ \\
\hline
\end{tabular}

\pm values indicate standard deviation

\section{Statistical analysis}

The data on each parameter were subjected to analyses of variance using Stat-view software. The least significant difference test at $P \leq 0.05$ was used to calculate significant differences between means of treatments. Regression plot was calculated between macro- and micro-elements in the composted manure with their concentrations in the spinach shoot.

\section{Results and discussion}

The relevant characteristics of soils and composted manure were given in Tables 1, 2 .

\section{Spinach biomass}

Spinach biomass significantly increased after the application of co-composted manure as compared to the manure without plant litter (Fig. 1). Among the treatments, the highest plant biomass observed with increasing manure: leaf litter ratios while the lower amount of biomass was obtained when manure was applied without tree litter (1:0). The plant biomass was higher in sandy loam soil as compared to the silt loam irrespective of the manure treatments. Spinach biomass enhanced by 62,105 and $142 \%$ in manure co-composted with leaf litter at 1:1, 1:2 and 1:3, respectively, in comparison to the composted manure of 1:0 in sandy loam soil. In case of silt loam soil, biomass increased by 39,70 and $109 \%$ for manure co-composted with the leaf litter at 1:1, 1:2 and 1:3, respectively, as compared to the manure composted at 1:0. The higher biomass yield at greater manure: leaf litter ratio may be due to the optimum availability of the essential plant nutrients. Incremental plant growth in the soils amended with manure indicated that the application of manure after co-composting might 

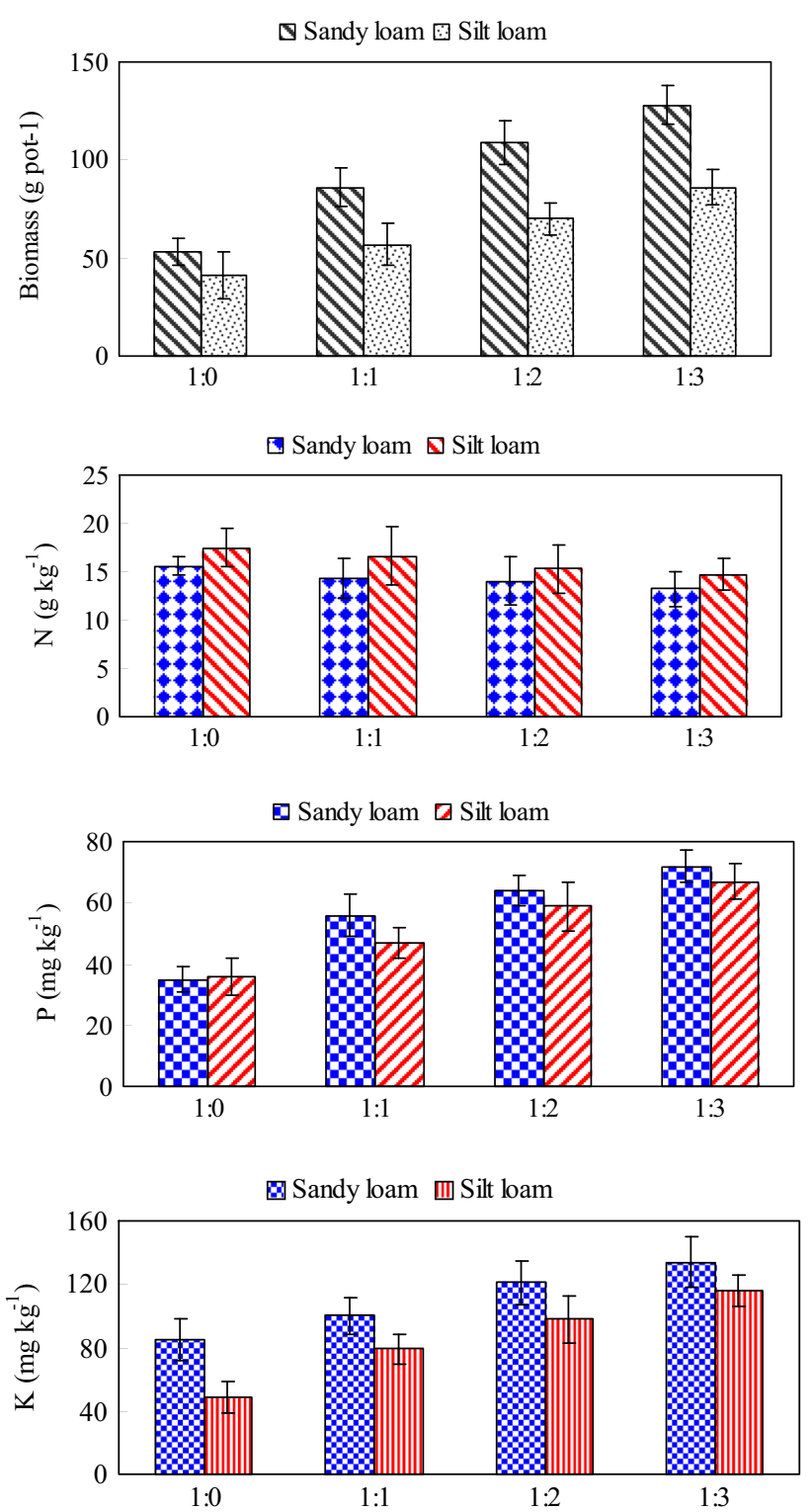

Fig. 1 Spinach biomass and nutrient contents in spinach shoot after application of composted and co-composted manure

be more complimentary to the plant development due to the nutrients availability and conversion of organic fractions into inorganic forms. The application of composted manure with tree residues proved to be a viable resource of essential plant nutrients. Irshad et al. (2002) reported higher biomass yield and promoted mineral concentrations in the maize grown in soil amended with composted manure. These results advocated enhancement of soil fertility subsequent to the application of composted manure. Several researchers have reported the significance of compost in triggering and enhancing soil fertility via supplying nutrients for plant use (Gul et al. 2016; Irshad et al. 2014). D'Hose et al. (2012) also confirmed that composted animal manure considerably increased dry matter yield of potatoes, fodder beets, forage maize and Brussels sprouts.

\section{Nutrient contents}

The application of co-composted manure significantly affected $\mathrm{N}$ content in spinach (Fig. 1). Increasing amount of leaf litter in the co-compost slightly reduced $\mathrm{N}$ content in the spinach as compared to the application of composted manure without leaf litter additives. Nitrogen contents in spinach shoot reduced by 15 and $13 \%$ in the mixture of manure and leaf litter of 1:3 as compared to 1:0 in sandy loam and silt loam soils, respectively. This might be related to the changes in the $\mathrm{N}$ composition of soil after adding cocomposted manure. Spinach exhibited higher $\mathrm{N}$ contents in the plant shoot grown in silt loam soil as compared to the sandy loam soil. Zai et al. (2008) demonstrated differential effects of composts in relation to the nutrient status for plant growth and development. Increased $\mathrm{N}$ bioavailability was reported after the application of composted manure to alfalfa and the increased nutrients availability from soil was associated with the improvement of soil properties (Malhi 2012).

Phosphorus contents in spinach significantly increased with the addition of leaf litter with the cow manure (Fig. 1). Phosphorus level in the shoot of spinach was lower, i.e., 35 and $36 \mathrm{mg} \mathrm{kg}^{-1}$ when grown in sandy loam and silt loam soil, respectively, treated with manure amendment of 1:0. Phosphorus contents in the spinach tissues increased by 60,82 and $105 \%$ in composted manure treatments of 1:1, 1:2 and 1:3, respectively, in the sandy loam soil. Phosphorus content increased by 30, 63 and $86 \%$, respectively, in silt loam soil. The variation of $\mathrm{P}$ content among spinach plants after manure amendments might be associated with the altered mineral composition of soils. Higher $\mathrm{P}$ content in plants with the addition of manure was reported by Huang et al. (2001). Irshad et al. (2002) reported that increasing composted manure application profoundly increased the nutrients uptake by plants for better growth. Moreover, poultry litter amendment in soil improved the elemental contents in maize (Faridullah et al. 2009). Mustafa et al. (2016) reported that muskmelon plants grown in media-containing guar or jantar composts had greater tissue nutrient concentrations as compared to other compost treatments.

Potassium content in plant tissue significantly increased with the application of co-composts as compared to the plants applied with the manure without leaf litter (Fig. 1). The $\mathrm{K}$ contents observed in the spinach shoot were 100 , 121 and $134 \mathrm{mg} \mathrm{kg}^{-1}$ in sandy loam soil after amendment with manure: leaf litter ratios of 1:1, 1:2 and 1:3, respectively. In silt loam soil, the $\mathrm{K}$ contents were 47,59 and 
$67 \mathrm{mg} \mathrm{kg}^{-1}$, respectively. Potassium increased in the plant shoot after applying co-compost mixed with greater amount of leaf litter. This indicated high quality of organic matter which might have affected the bioavailability of K. Increased $\mathrm{K}$ content has been attributed to the elemental contents of the composts, which improved the root growth and increased the nutrient uptake by plants (Aziz et al. 2006). Malhi (2012) reported that the application of organic manures favored the uptake of $\mathrm{N}, \mathrm{K}$ and $\mathrm{S}$ in wheat.

The application of co-composted manures decreased shoot contents of mico-elements. The contents of these elements in the spinach shoot varied in the order of $\mathrm{Zn}>\mathrm{Fe}>\mathrm{Cu}>\mathrm{Cd}$ (Fig. 2). When compared with the manure of 1:0, the manure amendment at 1:3 reduced the $\mathrm{Zn}$ contents in spinach from 45.1 to $23.1 \mathrm{mg} \mathrm{kg}^{-1}$ in sandy loam and from 48.3 to $25.4 \mathrm{mg} \mathrm{kg}^{-1}$ in silt loam soil. Iron concentrations in the spinach shoots were 27.3 and $37.5 \mathrm{mg} \mathrm{kg}^{-1}$ and $\mathrm{Cu}$ concentrations were 4.5 and $5.1 \mathrm{mg} \mathrm{kg}^{-1}$ and $\mathrm{Cd}$ concentrations were 1.4 and $1.8 \mathrm{mg} \mathrm{kg}^{-1}$ in sandy loam and silt loam soil, respectively, after amendment with composted manure (1:0). The $\mathrm{Zn}$ contents reduced to 23.1 and $25.4 \mathrm{mg} \mathrm{kg}^{-1}$, Fe contents were 9.6 and $17.8 \mathrm{mg} \mathrm{kg}^{-1}, \mathrm{Cu}$ contents were 3 and $3.4 \mathrm{mg} \mathrm{kg}^{-1}, \mathrm{Cd}$ contents were 0.8 and $0.6 \mathrm{mg} \mathrm{kg}^{-1}$ in plants grown in sandy loam and silt loam soil, respectively, after amendment with co-composted manure at 1:3. Low availability of trace elements after the application of cocomposted manure with increasing amounts of leaf litter may be responsible for the lower trace elements contents in the spinach. Generally water-extractable fractions of trace elements are easily available to the plants and associated with the noxious and integral component of composts (Singh and Kalamdhad 2014). The reduction in trace elements composition in spinach plants could also be related to the amount and nature of the organic matter. Organic fraction of soil affected the interactions and availability of trace elements in soil by the formation of varyingly stable organometallic complexes called chelates by binding and holding insoluble metal ions and compounds with the $\mathrm{OH}$ and $-\mathrm{COOH}$ groups. Such compounds are enriched by cattle manure which consequently may limit metal solubility and bioavailability in soils (Liu et al. 2009; Singh et al. 2015). Heavy metals in soil are held and bound by organic compounds and are not available for plant uptake if these complexes are in soluble, but they are slowly released occurring through microbial decomposition (Guan et al. 2011). Trace elements contents in spinach shoot were higher in silt loam soil than sandy loam soil, irrespective of the type of compost applied. Silveira et al. (2003) reported that the application of potentially mineralized organic matter after the composting resulted in the formation of strong binding sites in soil which diminished heavy metal
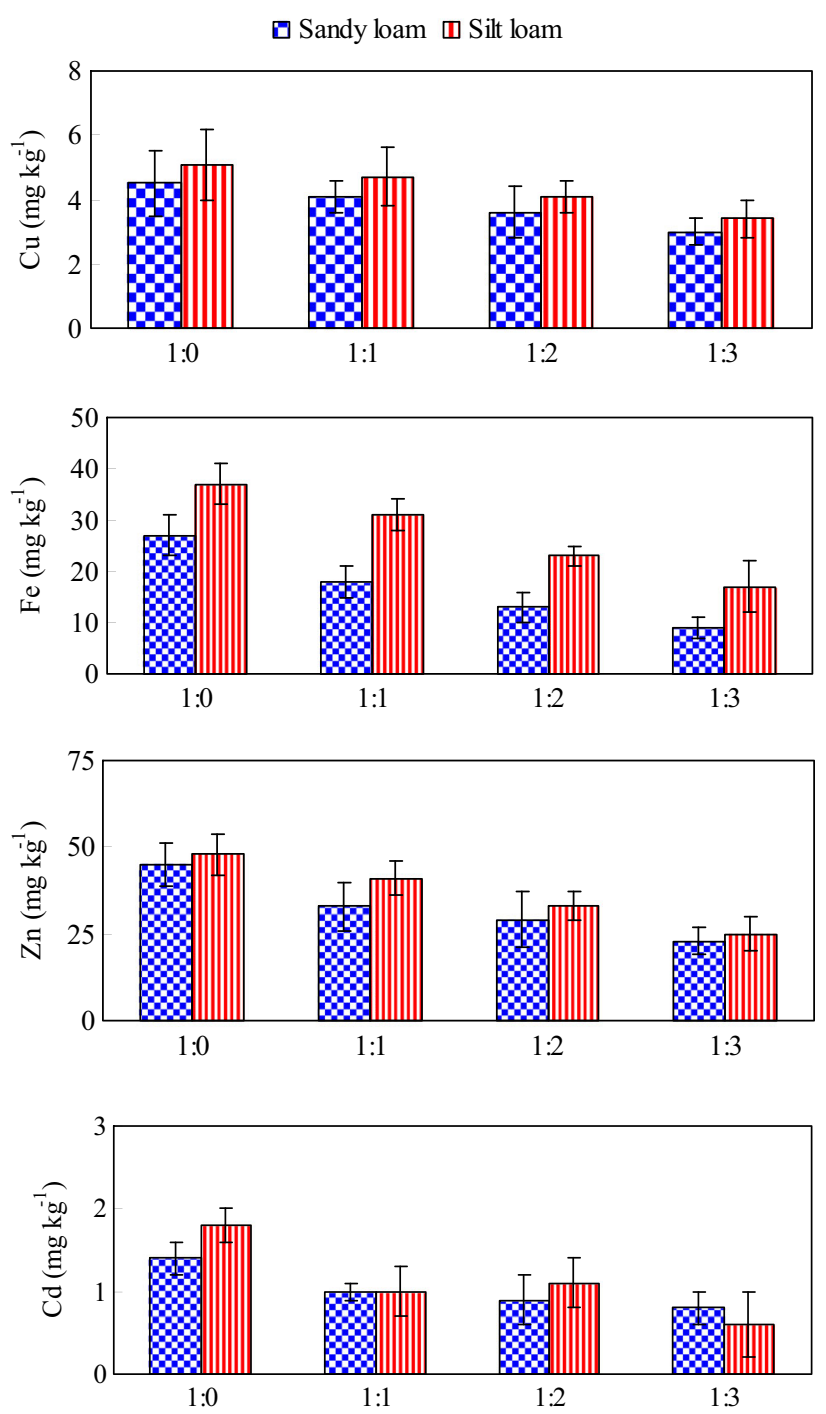

Fig. 2 Micro-elements concentrations in spinach shoot after application of co-composted manure

uptake by plants. Likewise, Singh et al. (2015) reported reduced bioavailability of heavy metals to plants after application of agitated pile co-composted cattle manure with the rice husk. Composting may reduce the mobility of heavy metals and thus their transport to the environment in contrast to the fresh manure. The utilization of composted manure was advantageous and worthwhile in adulterated soils for alleviating heavy metal contamination ( Gul et al. 2016).

Regression equations and determinant $\left(R^{2}\right)$ explaining the relationships of nutrient contents in spinach shoot $(Y)$ to their contents in co-composted manure $(X)$ are given in Fig. 3. The higher $R^{2}$ values for $\mathrm{P}, \mathrm{K}$ and $\mathrm{Zn}$ showed that the contents of these nutrients elements in spinach shoot were highly dependent on their contents in the co-compost applied to the soil. The other elements were also found positively associated with the composition of co-compost. 


\section{Nutrients extractability from post-harvest soil}

The application of manure compost in soil significantly affected the extractability of essential plant nutrients. The application of composted manure with plant litter significantly improved soil $\mathrm{P}$ contents and its uptake by spinach (Table 3). The soil amendment of higher quantity of poplar leaf litter with manure at the ratios of $1: 1,1: 2$ and $1: 3$ enhanced soil P by 22, 35 and $51 \%$ in sandy loam and 14, 39 and $53 \%$ in silt loam soil, respectively. Eichler-Löbermann et al. (2007) reported increased soil P content after application of manure compost. In the present work, $\mathrm{P}$ contents were noticed as 31 and $28 \mathrm{mg} \mathrm{kg}^{-1}$ in sandy loam and silt loam soil, respectively, after amendment with compost without leaf litter.

Conversely, the application of co-compost decreased total $\mathrm{N}$ content particularly with increasing amount of leaf litter irrespectively of the soil type (Table 3). Nitrogen content of the soil could vary due to the nutrient status of the co-composts of cow manure. The N-enriched manure source after the incorporation of increased amount of leaf litter reduced the $\mathrm{N}$ level of soils. The $\mathrm{N}$ content in sandy loam soil was found more than that of silt loam soil. Wolka and Melaku (2015) reported significantly lower $\mathrm{N}$ and organic carbon after manure addition in soil. Giannakis et al. (2014) demonstrated that compost application gradually reduced soil $\mathrm{N}$ and organic $\mathrm{C}$. This declining trend of $\mathrm{N}$ might also be due to leaching and/or nitrification etc. Contradictory results of increased $\mathrm{N}$ after different levels of compost application have been reported by Nguyen and Shindo (2011). Likewise, significant increase in the $\mathrm{N}$ and $\mathrm{P}$ was noticed subsequent to the application of chicken manure (Dikinya and Mufwanzala 2010).

Nitrate and $\mathrm{NH}_{4}-\mathrm{N}$ fluctuated in accordance with the soil-type and mixing ratios of leaf litter and manure. The contents had inverse relation with the proportion of leaf additives in manure. The greater amount of leaf litter in the manure lowered the $\mathrm{NO}_{3}-\mathrm{N}$ and $\mathrm{NH}_{4}-\mathrm{N}$ contents in both soils. For instance, sandy loam soil showed significantly declined $\mathrm{NO}_{3}-\mathrm{N}$ content $\left(8.2,7.6,6.4\right.$ and $5.7 \mathrm{mg} \mathrm{kg}^{-1}$ )
Fig. 3 Regression between macro- and micro-elements in co-compost applied versus these elements in spinach shoot. The contents of all elements in spinach shoot and co-compost are expressed in $\mathrm{mg} \mathrm{kg}^{-1}$ except $\mathrm{N}$ values, i.e., $\mathrm{g} \mathrm{kg}^{-1}$
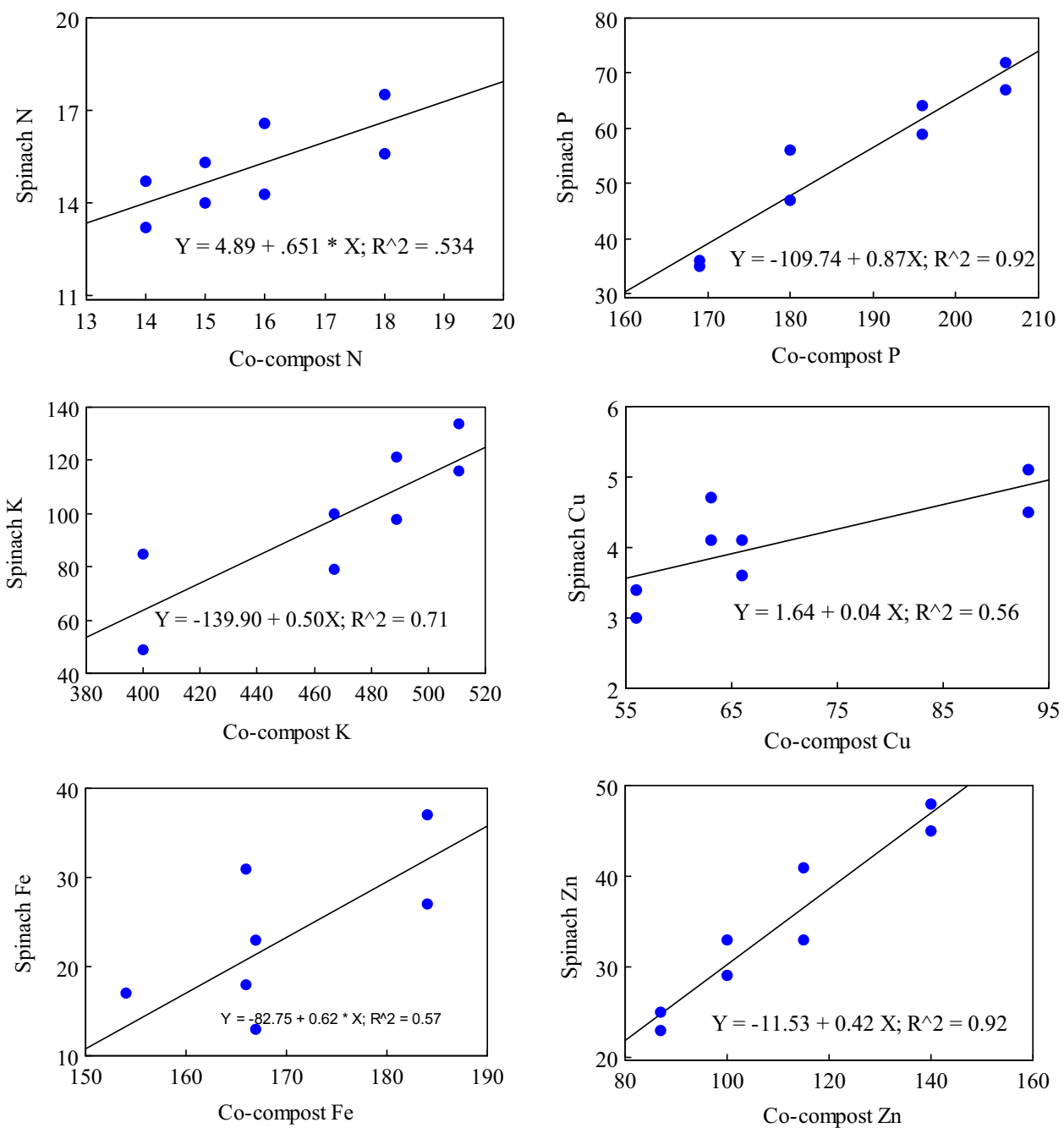
Table 3 Changes in plant macro- and micro-elements $\left(\mathrm{mg} \mathrm{kg}^{-1}\right)$ in post-harvest soil applied with co-composted cow manure $(\mathrm{CM})$ with plant litter (PL)

\begin{tabular}{lllllllllll}
\hline Soil & $\mathrm{CM}: \mathrm{PL}$ & $\begin{array}{l}\mathrm{N} \\
\mathrm{g} \mathrm{kg}^{-1}\end{array}$ & $\mathrm{NO}_{3}-\mathrm{N}$ & $\begin{array}{l}\mathrm{NH}_{4}-\mathrm{N} \\
\mathrm{mg} \mathrm{kg}^{-1}\end{array}$ & $\mathrm{P}$ & $\mathrm{K}$ & $\mathrm{Cu}$ & $\mathrm{Zn}$ & $\mathrm{Fe}$ & $\mathrm{Cd}$ \\
\hline Sandy loam & $1: 0$ & 2.3 & 8.2 & 6.8 & 31 & 61 & 3.6 & 36.7 & 14.1 & 0.8 \\
& $1: 1$ & 2.1 & 7.6 & 5.9 & 38 & 88 & 3.0 & 28.4 & 10.1 & 0.9 \\
& $1: 2$ & 1.8 & 6.4 & 5.0 & 42 & 103 & 2.7 & 24.8 & 8.7 & 0.6 \\
& $1: 3$ & 1.5 & 5.7 & 4.3 & 47 & 120 & 2.4 & 20.7 & 6.5 & 0.6 \\
Silt loam & $1: 0$ & 2.1 & 9.1 & 7.2 & 28 & 32 & 4.1 & 58.2 & 20.1 & 0.9 \\
& $1: 1$ & 1.9 & 7.8 & 6.6 & 32 & 46 & 3.5 & 51.9 & 15.6 & 0.8 \\
& $1: 2$ & 1.6 & 7.1 & 5.8 & 39 & 65 & 3.0 & 45.3 & 13.5 & 0.7 \\
& $1: 3$ & 1.3 & 6.1 & 4.7 & 43 & 89 & 2.5 & 41.5 & 10.4 & 0.6 \\
LSD (0.05) & & 0.1 & 0.7 & 0.8 & 1.3 & 3.4 & 0.6 & 1.7 & 0.8 & 0.1 \\
\hline
\end{tabular}

after compost amendment of 1:0,1:1,1:2 and 1:3. Similarly, the lower $\mathrm{NO}_{3}-\mathrm{N}$ content of $6.1 \mathrm{mg} \mathrm{kg}^{-1}$ was observed in manure leaf ratio of 1:3 in silt loam soil as compared to $9.1 \mathrm{mg} \mathrm{kg}^{-1}$ in compost amendment of 1:0. The reduced $\mathrm{NO}_{3}-\mathrm{N}$ level in the soils applied with cocomposts of considerable leaf additives could be related to the immobilization and/or denitrification of the cumulated $\mathrm{NO}_{3}-\mathrm{N}$. Furthermore, irrespective of the soil type, $\mathrm{NH}_{4}-\mathrm{N}$ was profoundly reduced after co-composts applications. Among compost amendments, the $\mathrm{NH}_{4}-\mathrm{N}$ contents in the soil varied in the order of $1: 0>1: 1>1: 2>1: 3$. Cocomposts treated soils better reduced the $\mathrm{NH}_{4}$ release as compared to the soils amended with compost without tree litter (1:0) which stressed on the negative relationship of soil- $\mathrm{NH}_{4}$ to the increased ratios of leaf additives in the cocompost. Similarly, declined $\mathrm{NO}_{3}$ was reported in compost amended turf-grass soil (Wright et al. 2007).

Soils amended with co-compost increased the available $\mathrm{K}$ content, particularly with increasing ratio of poplar leaf litter (Table 3). This indicated the effectiveness of organic matter for the $\mathrm{K}$ availability in the soil. The maximum $\mathrm{K}$ content of $120 \mathrm{mg} \mathrm{kg}^{-1}$ was noted in sandy loam soil and $89 \mathrm{mg} \mathrm{kg}^{-1}$ in silt loam soil after the manure application of leaf litter at 1:3. The $\mathrm{K}$ release dynamics could be attributed to the elemental properties of the manure composted at different ratios along leaf litter. Huang et al. (2001) reported leaf litter as a potential source of nutrients for soil fertility and crop production if co-composted with N-enriched source of cattle manure (Table 4). The application of manure amendment of 1:0 to sandy loam and silt loam soils resulted in $\mathrm{K}$ contents of 61 and $32 \mathrm{mg} \mathrm{kg}^{-1}$, respectively. The reduced availability of $\mathrm{K}$ through the manure application without leaf litter may be due to the dilution effect. Among amended soils, $\mathrm{K}$ differed in the order sandy loam $>$ silt loam. This alteration in the $\mathrm{K}$ extraction could be attributed to the modified properties of soil after manure amendments. Phosphorus and $\mathrm{K}$ availability in soil and their uptake by plants were enhanced by
Table 4 Changes in $\mathrm{pH}$ and EC in post-harvest soil applied with cocomposted cow manure $(\mathrm{CM})$ with plant litter $(\mathrm{PL})$

\begin{tabular}{llll}
\hline Soil & CM:PL & $\mathrm{pH}$ & $\begin{array}{l}\mathrm{EC} \\
\mathrm{dS} \mathrm{m} \mathrm{m}^{-1}\end{array}$ \\
\hline Sandy loam & $1: 0$ & 7.1 & 1.8 \\
& $1: 1$ & 7.4 & 2.2 \\
& $1: 2$ & 7.5 & 2.2 \\
Silt loam & $1: 3$ & 7.6 & 2.6 \\
& $1: 0$ & 7.0 & 1.7 \\
& $1: 1$ & 7.2 & 1.9 \\
LSD (0.05) & $1: 2$ & 7.4 & 2.0 \\
\hline
\end{tabular}

organic manure (Aziz et al. 2010; Cavigelli and Thien 2003).

The micro-element contents in both soils altered in the order of $\mathrm{Zn}>\mathrm{Fe}>\mathrm{Cu}>\mathrm{Cd}$ regardless of the co-composts applied. Incorporation of manure amendment to the soils reduced the availability of trace elements and consequently reduced their uptake by spinach. Zinc contents of sandy loam and silt loam soils declined by 44.9 and $29.3 \%$ with the application manure: leaf litter of $1: 3$ as compared to the manure treatment without leaf litter (1:0). Zinc content in soil was within the threshold range of $14-125 \mathrm{mg} \mathrm{kg}^{-1}$. Zinc concentrations in the soils varied with the co-composted manure in the order of $1: 0>1: 1>1: 2>1: 3$. This reduction might possibly be related to the effective mineralization of the organic manure with the leaf litter additives that could efficiently adsorbed inorganic $\mathrm{Zn}$. Similar finding of reduced metals availability in soil mixed with composted animal manure in contrast to soil amended with the fresh manures was reported earlier (Irshad et al. 2014). The utilization of composted manure instead of fresh manure in metal contaminated soils could be more advantageous in alleviating heavy metal pollution (Gul et al. 2016). 
The co-composts reduced the extractable Fe in soil. The Fe content in the sandy loam soil was reduced by $53 \%$ with the application of manure: leaf litter at 1:3 ratio as compared to the manure minus leaf litter (1:0). The efficient reduction with the application of co-compost could be attributed to the potential source of essential nutrients and the drop of heavy metals in the soils. The fluctuations observed in the release of Fe could be related to the elemental status of the co-composts applied to the soil. The effectiveness of the manure product could be associated with the formation of organometallic complexes that hold more $\mathrm{Fe}$ and reduced the $\mathrm{Fe}$ uptake by spinach plants. Furthermore, basic $\mathrm{pH}$ of soil helps to adsorb cationic metals on organic matter sites. The $\mathrm{pH}$ is evaluated as the controlling factor of ion exchange, redox reactions, adsorption and complexation reactions (Walter et al. 2006). The effectiveness of heavy metal solubility after manure compost application was determined by the extent of organic matter humification and the successive ramification on soil pH (Gupta and Sinha 2007).

Copper content of the soils demonstrated an inverse relationship with the application of compost. Lower $\mathrm{Cu}$ content was found in sandy loam soil $\left(2.4 \mathrm{mg} \mathrm{kg}^{-1}\right)$ applied with 1:3 manure amendment as compared to the soil amended with manure without leaf litter having $\mathrm{Cu}$ content of $3.6 \mathrm{mg} \mathrm{kg}^{-1}$. Similarly, silt loam soil amended with manure amendments of 1:0,1:1, 1:2 and 1:3 exhibited $\mathrm{Cu}$ contents of $4.1,3.5,3.0$ and $2.5 \mathrm{mg} \mathrm{kg}^{-1}$. Reduced $\mathrm{Cu}$ release from compost amended soil might be associated with the progressive humification of organic manure applied and the formation of stabilized $\mathrm{Cu}$ complexes with humic substances (McLaren and Clucas 2001). Compost and poultry manure amendments were recommended for the optimization of $\mathrm{Cu}$ in contaminated soil (Thomas and Dauda 2015). A marked reduction in extractable Cd was recorded in soils after co-composts application. Cd level fluctuations in soils depended on the composting ratios and varied as 1:3<1:2<1:1<1:0. For instance, extractable $\mathrm{Cd}$ decreased by $25 \%$ in sandy loam soil and $32 \%$ in silt loam amended with manure: leaf litter ratio of $1: 3$ as compared to the manure without leaf litter. The maximum permissible limit of $\mathrm{Cd}$ in soil was reported as $5 \mathrm{mg} \mathrm{kg}^{-1}$ (Dudka et al. 1994). Therefore, the Cd contents in soil samples were found within permissible limits during this study.

\section{EC and pH of post-harvest soil}

The respective EC of sandy loam and silt loam soil was 1.8 and $1.7 \mathrm{dS} \mathrm{m}^{-1}$ applied with composted manure without leaf additives in contrast to the soils amended with 1:3 of co-composts where the EC values were 3.1 and $2.9 \mathrm{dS} \mathrm{m}^{-1}$, respectively. Comparatively, silt loam soil amended with 1:1, 1:2 and 1:3 composted manure with leaf litter exhibited EC values of 1.9, 2.0 and $2.2 \mathrm{dS} \mathrm{m}^{-1}$, respectively. This increase may be attributed to the greater pool of soluble cations in the cocomposts and their release in the respective soil. It was found that co-composts application increased the soluble salts contents in the post-harvest soils that directly measure the salinity after decomposition and the mobilization of organic matter. Dikinya and Mufwanzala (2010) reported increased EC values with the increasing application rates of manure. Results of higher EC values after manure applications in soils have also been reported by different authors (Loper et al. 2010; Wolka and Melaku 2015).

Soil $\mathrm{pH}$ slightly differed with the leaf litter application in the manure. The compost demonstrated slightly alkaline $\mathrm{pH}$ (7.1-7.6) in sandy loam soil and 7.0-7.5 in silt loam soil. With the application of 1:3 co-composted manure the $\mathrm{pH}$ value increased from 7.1 to 7.6 in sandy soil and 7.0-7.5 in silt loam soil. High soil $\mathrm{pH}$ for composted manure was also reported by Scharenbroch (2009). On the other hand, a low soil $\mathrm{pH}$ after compost amendment was reported by Loper et al. (2010).

\section{Conclusions}

Significant impact of co-compost on the bioavailability and extractability of plant nutrients in soils was evident. Dry biomass, $\mathrm{P}$ and $\mathrm{K}$ contents in spinach shoot enhanced with the application of manure co-composted at different ratio of leaf litter. Conversely $\mathrm{N}, \mathrm{Zn}, \mathrm{Fe}, \mathrm{Cu}$ and $\mathrm{Cd}$ contents in spinach declined with the application of manure amendment co-composted with increasing amount of leaf litter. Chemical composition of co-compost significantly altered the availability of trace elements in the order of $\mathrm{Cd}<\mathrm{Cu}<\mathrm{Fe}<\mathrm{Zn}$. Micro-elements contents in plants and post-harvest soils were inversely related to the increased amount of leaf additives in the composted manure. Nitrogen content in the post-harvest soil decreased in the sequence of $1: 1>1: 2>1: 3$ of the co-composts. The lower availability of micro-elements in manure may recommend it for the safe and productive utilization in soils.

Acknowledgements We acknowledge Life Sciences Department, COMSATS Institute of Information Technology, Abbottabad, for provision of the lab facilities.

Open Access This article is distributed under the terms of the Creative Commons Attribution 4.0 International License (http://crea tivecommons.org/licenses/by/4.0/), which permits unrestricted use, distribution, and reproduction in any medium, provided you give appropriate credit to the original author(s) and the source, provide a link to the Creative Commons license, and indicate if changes were made. 


\section{References}

Agbede TM, Ojeniyi SO, Adeyemo AJ (2008) Effect of poultry manure on soil physical and chemical properties, growth and grain yield of sorghum in southwest, Nigeria. Am Eur J Sustain Agric 2:72-77

Anderson JM, Ingram JSI (1993) Tropical soil biology and fertility, a handbook of methods, 2nd edn. CABI, Wallingford

Aziz T, Rahmatullah MA, Maqsood MA, Tahir IA, Cheema MA (2006) Phosphorus utilization by six Brassica cultivars (Brassica juncea $\mathrm{L}$.) from tri-calcium phosphate; a relatively insoluble $\mathrm{P}$ compound. Pak J Bot 38:1529-1538

Aziz T, Samiullah SA, Nasim M, Farooq M, Khan MM (2010) Nutrient availability and maize growth in soil amended with organic manure. Int J Agric Biol 12(4):621-624. doi:10.1016/ S0960.8524(02)00042-1

Azza E, Hideto U, Abdel G, Naomi A (2007) Uptake of carbon and nitrogen through rice root from $13 \mathrm{C}$ and $15 \mathrm{~N}$ dual labelled maize residue compost. Int J Biol Chem 1:75-83. doi:10.1007/s11104008-9543-2

Benjawan L, Sihawong S, Chayaprasert W, Liamlaem W (2015) Composting of biodegradable organic waste from Thai household in a semi-continuous composter. Compost Sci Util 23:11-17. doi:10.1080/1065657X.2014.963742

Cavigelli MA, Thien SJ (2003) Phosphorus bioavailability following incorporation of green manure crops. Soil Sci Soc Am J 67:1186-1194

Chaudhry MG, Ahmad MS, Chaudhry GM (1999) Growth of livestock production in Pakistan: an analysis. Pak Dev Rev 38(4):605-614

D’Hose T, Cougnon M, De Vliegher A, Willekens K, Van Bockstaele E, Rehe D (2012) Farm compost application: effects on crop performance. Compost Sci Util 20:49-56. doi:10.1080/1065657X.2012. 10737022

Dikinya O, Mufwanzala N (2010) Chicken manure enhanced soil fertility and productivity: effects of application rates. J Soil Sci Environ Manag 1(3):46-54

Dudka S, Piotrowska M, Chlopecka A (1994) Effect of elevated concentrations of $\mathrm{Cd}$ and $\mathrm{Zn}$ in soil on spring wheat yield and the metal contents of the plants. Water Air Soil Pollut 76:333-341

Eichler-Löbermann B, Köhne S, Köppen D (2007) Effect of organic, inorganic, and combined organic and inorganic $\mathrm{P}$ fertilization on plant $\mathrm{P}$ uptake and soil $\mathrm{P}$ pools. J Plant Nutr Soil Sci 170:623-628. doi:10.1002/jpln.200620645

Faridullah IM, Yamamoto S, Eneji AE, Uchiyama T, Honna T (2009) Recycling of chicken and duck litter ash as a nutrient source for Japanese mustard spinach. J Plant Nutr 32:1082-1091. doi:10. 1080/01904160902943122

Gee GW, Bauder JW (1986) Particle-size analysis. In: Klute A (ed) Method of soil analysis. Part 1. Agronomy series No. 9. ASA, SSSA, Madison

Giannakis GV, Kourgialas NN, Paranychianakis NV, Nikolaidis NP, Kalogerakis N (2014) Effects of municipal solid waste compost on soil properties and vegetables growth. Compost Sci Util 22:116-131. doi:10.1080/1065657X.2014.899938

Guan TX, He HB, Zhang XD, Bai Z (2011) Cu fractions, mobility and bioavailability in soil-wheat system after $\mathrm{Cu}$-enriched livestock manure applications. Chemosphere 82:215-222. doi:10.1016/ chemosphere.2010.10.018

Gul S, Naz A, Khan A, Nisa S, Irshad M (2016) Phytoavailability and leachability of heavy metals from contaminated soil treated with composted livestock manure. Soil Sediment Contam 25:181-194. doi: $10.1515 /$ pjct-2015-0044
Gupta AK, Sinha S (2007) Phytoextraction capacity of the plants growing on tannery sludge dumping sites. Bioresour Technol 98:1788-1794. doi:10.1016/j.biortech.2006.06.028

Huang GF, Fang M, Wu QT, Zhou LX, Liao XD, Wong JWC (2001) Co-composting of pig manure with leaves. Environ Technol 22:1203-1212. doi:10.1080/09593332208618207

Irshad M, Yamamoto S, Eneji AE, Honna T, Endo T (2002) Influence of composted manure and salinity on growth and nutrient content of maize tissue. Sand Dune Res 49:1-10

Irshad M, Gul S, Eneji AE, Anwar Z, Ashraf M (2014) Extraction of heavy metals from manure and their bioavailability to spinach after composting. J Plant Nutr 37:1661-1675. doi:10.1080/ 01904167.2014.888748

Keeney DR, Nelson DW (1982) Nitrogen-Inorganic forms. In: page AL, Miller RH, Keeney DR (eds) Methods of Soil Analysis part 2: Chemical and microbiological properties, Agronomy 9/2, 2nd edn. American society of Agronomy, Madison, WI, pp 643-698

Li X, Zhang R, Pang Y (2008) Characteristics of dairy manure composting with rice straw. Biores Technol 99:359-367. doi:10. 1016/j.biortech.2006.12.009

Liu L, Hansong C, Peng C, Wei L, Qiaoyun H (2009) Immobilization and phytotoxicity of $\mathrm{Cd}$ in contaminated soil amended with chicken manure compost. J Hazard Mater 163:563-567. doi:10. 1016/j.jhazmat.2008.07.004

Loper S, Shober AL, Wiese C, Denny GC, Stanley CD (2010) Organic soil amendment and tillage affect soil quality and plant performance in stimulated residential landscape. Hort Sci 45:1522-1528

Malhi SS (2012) Relative effectiveness of various amendments in improving yield and nutrient uptake under organic crop production. Open J Soil Sci 2:299-311. doi:10.4236/ojss.2012.23036

McLaren RG, Clucas LM (2001) Fractionation of copper, nickel, and zinc in metal-spiked sewage sludge. J Environ Qual 30:1968-1975

Miller RO (1998) Nitric-perchloric acid wet digestion in an open vessel. In: Kalra Y (ed) Handbook of reference methods for plant analysis. CRC Press, Washington

Mrabet L, Belghyti D, Loukili A, Attarassi B (2012) Effect of household waste compost on the productivity of maize and lettuce. Agric Sci Res J 2(8):462-469

Muhammad D, Khattak RA (2009) Growth and nutrient concentration of maize in pressmud treated saline-sodic soils. Soil Environ 28:145-155

Mustafa G, Ali MA, Smith D, Schwinghamer T, Lamont JR, Ahmed N, Hussain S, Arshad M (2016) Guar, jantar, wheat straw, and rice hull composts as replacements for peat in muskmelon transplant production. Int J Recycl Org Waste Agric 5:323-332. doi:10.1007/s40093-016-0142-6

Nelson DW, Sommers LE (1982) Total carbon, organic carbon and organic matter. In: Page AL, Miller RH, Keeney DR (eds) Methods of soil analysis. Part 2. Chemical and microbiological properties. ASA, SSSA, Madison, pp 539-580

Nguyen TH, Shindo H (2011) Effects of different levels of compost application on amounts and distribution of organic nitrogen forms in soil particle size fractions subjected mainly to double cropping. Agric Sci 2(3):213-219. doi:10.4236/as.2011.23030

Olsen SR, Sommers LE (1982) Phosphorus. In: Page AL et al (eds) Methods of soil analysis, Part 2, 2nd edn, Agronomy Monograph 9. ASA and ASSA, Madison, pp 403-430

Scharenbroch BC (2009) A meta-analysis of studies published in arboriculture and urban forestry relating to organic materials and impacts on soil, tree, and environmental properties. Arboric Urban For 35:221-231

Silva BMT, Menduíña AM, CendónSeijo Y, Viqueira DF (2007) Assessment of municipal solid waste compost quality using 
standardized methods before preparation of plant growth media. Waste Manag Res 25:99-108

Silveira MLA, Alleoni LRF, Guilherme LRG (2003) Biosolids and heavy metals in soils. Sci Agric 60:793-806. doi:10.1590/S010390162003000400029

Singh J, Kalamdhad AS (2014) Effect of lime on speciation of heavy metals during agitated pile composting of water hyacinth. Front Environ Sci Eng (FESE) 10:10-22. doi:10.1007/s11783-0140704-7

Singh WR, Pankaj SK, Kalamdhad AS (2015) Reduction of bioavailability and leachability of heavy metals during agitated pile composting of Salvinianatans weed of Loktak Lake. Int J Recycl Org Waste Agric 4:143-156. doi:10.1007/s40093-0150094-2

Thomas EY, Dauda SO (2015) Comparative effects of compost and poultry manure on bioavailability of $\mathrm{Pb}$ and $\mathrm{Cu}$ and their uptake by maize. New York Sci J 8:72-81

Torkashvand AM, Alidoust M, Khomami AM (2015) The reuse of peanut organic wastes as a growth medium for ornamental plants. Int J Recycl Org Waste Agric 4(2):85-94. doi:10.1007/ s40093-015-0088-0

Walter I, Martinez F, Cala V (2006) Heavy metal speciation and phytotoxic effects of three representative sewage sludge for agricultural uses. Environ Pollut 139:507-514. doi:10.1016/j. envpol.2005.05.020

Wolka K, Melaku B (2015) Exploring selected plant nutrient in compost prepared from food waste and cattle manure and its effects on soil properties and maize yield in Wondo Genet, Ethopia. Environ Syst Res 4:1-7. doi:10.1186/s40068-015-00350

Wright AL, Provin TL, Hons FM, Zuberer DA, White RH (2007) Nutrient accumulation and availability in compost amended turfgrass soil. HortSci 42:1473-1477

Zai AKE, Takatsugu H, Tsutomu M (2008) Effects of compost and green manure of pea and their combinations with chicken manure and rapeseed residue on soil fertility and nutrient uptake in wheat-rice cropping system. Afr J Agric Res 3:633-639 